\title{
Pre-starter feed thermally processed to feed broiler chicks
}

Ração pré-inicial processada termicamente na alimentação de pintos de corte

\author{
SOUSA $^{1 *}$, Regina Fialho de \\ https://orcid.org/0000-0002-9439-843X \\ LEANDRO $^{1}$, Nadja Susana Mogyca \\ https://orcid.org/0000-0002-6525-9975 \\ CARVALHO ${ }^{1}$, Fabyola barros de \\ https://orcid.org/0000-0001-5900-5437
}

\author{
STRINGHINI ${ }^{1}$, José Henrique \\ https://orcid.org/0000-0002-3710-6963 \\ CAFÉ $^{1}$, Marcos Barcello \\ https://orcid.org/0000-0002-1478-8009
}

JARDIM FILHO ${ }^{1}$, Roberto Moraes

https://orcid.org/0000-0001-8810-1284

REZENDE $^{1}$, Pedro Moraes

https://orcid.org/0000-0002-7414-4010

\footnotetext{
${ }^{1}$ Universidade Federal de Goiás, Escola de Veterinária e Zootecnia, Departamento de Zootecnia, Goiânia, Goiás, Brasil

*Mail for correspondence: regina-so-fia@hotmail.com
}

\begin{abstract}
The objective of this study was to evaluate the thermal processing of pre-initial diets on performance, morphometry of the organs of the digestive system and nutrient digestibility in broiler chicks. The test sample consisted of 180 broiler chicks distributed in a completely randomized design, with two treatments, six replications of 15 birds each. The treatments consisted of pelleted feed $\left(70^{\circ} \mathrm{C}\right)$ and extruded feed $\left(150^{\circ} \mathrm{C}\right)$. The metabolism test was realized from 4 to 7 days of age, while the performance and morphometry of the organs of the digestive system were evaluated at 7 and 21 days of age. The data were submitted to analysis of variance. At seven days of age, chicks that consumed extruded feed had lower feed intake, less development of digestive tract organs, lower nitrogen absorption rate, dry matter, in addition to less metabolizable energy compared to pelleted feed. Likewise, at 21 days of age, chicks that consumed extruded pre-starter feed performed worse than pelleted feed. The conclusion is thus reached that feed extruded at $150{ }^{\circ} \mathrm{C}$ for broiler chicks in the pre-initial phase, results in lower nutrient digestibility and an inferior development of the organs of the digestive system at 7 days of age and worse performance at 21 days.
\end{abstract}

Key words: biometrics, chickens, digestibility, extrusion, pelletization 


\section{RESUMO}

Objetivou-se avaliar o processamento térmico de rações pré-iniciais sobre o desempenho, morfometria dos órgãos do sistema digestório e metabolizabilidade dos nutrientes das rações de pintos de corte. Foram utilizados 180 pintos de corte, distribuídos em delineamento inteiramente casualizado, com dois tratamentos, seis repetições de 15 aves cada. Os tratamentos consistiram em ração peletizada $\left(70^{\circ} \mathrm{C}\right)$ e ração extrusada $\left(150^{\circ} \mathrm{C}\right)$. $\mathrm{O}$ ensaio de metabolizabilidade foi realizado de quatro a sete dias de idade, enquanto o desempenho e morfometria dos órgãos do sistema digestório foram avaliados aos sete e 21 dias de idade. Os dados foram submetidos à análise de variância. Aos sete dias de idade, os pintos que consumiram ração extrusada apresentaram menor consumo de ração, menor desenvolvimento dos órgãos do trato digestório, pior metabolizabilidade do nitrogênio, matéria seca, além de menor energia metabolizável em relação a ração peletizada. Do mesmo modo, aos 21 dias de idade, os pintos que consumiram ração préinicial extrusada apresentaram pior desempenho em relação a ração peletizada. Concluise que ração extrusada a $150^{\circ} \mathrm{C}$ para pintos de corte na fase pré-inicial, resulta em menor metabolizabilidade dos nutrientes e menor desenvolvimento dos órgãos do sistema digestório aos sete dias de idade e pior desempenho aos 21 dias.

Palavras-chave: biometria, metabolizabilidade, extrusão, frangos, peletização

\section{INTRODUCTION}

The pre-initial phase of a broiler chicken represents $20 \%$ of its productive life (Lamot et al., 2014) and as such this period requires special attention, as chick performance during the pre-initial phase has a profound influence on the end performance of the batch. According to Leeson \& Summers (2005), for each additional gram of live weight reached at 7 days of age represents at least 5 grams of extra weight at slaughter. There occurs also in this phase, the physical and functional development of the digestive system, which increases the capacity to digest and absorb nutrients (Freitas et al., 2008). According to Dos Santos et al.(2019), broiler chicks present an increase of up to $300 \%$, in relative weight of the intestinal tract, during the first four days of life. Likewise in Freitas et al.(2008), the highest intestinal development is related to greater area of absorption, which results in greater performance of broilers.

Research has demonstrated that the development of secretory and absorptive functions in the digestive system depend on the presence of food in the intestinal lumen. For Ebling et al. (2015), preinitial feeds should be the best quality possible to compensate the lower capacity of digestion in this phase, as well as to stimulate the development of the digestive tract. According to Boemo et al. (2016), the supply of thermally processed pre-initial feed can compensate the lower capacity of digestion in broiler chicks, in view of the improved metabolizable energy provided by thermal processing, over that of conventional mash feed.

Thermal processing, such as pelletizing and extrusion, increase the availability of nutrients for digestion (Avazkhanloo et al., 2020). Pelletizing causes a pre- 
gelatinization of starch (Massuquetto et al., 2018), and extrusion causes greater modification to the carbohydrates and protein, as these processes involve temperatures of up to $150^{\circ} \mathrm{C}$ (Al-rabadi et al., 2011).

Information on the use of extruded feeds for broiler chicks is still limited, where there exist doubts as to whether the process of extrusion increases the metabolizable energy of the nutrients in the feed or improves the results for zootechnical performance. Therefore, the objective behind this study is to evaluate the effect of thermal processing (extrusion and pelletization) of preinitial feed for broiler chicks on the metabolizing of nutrients, performance and morphometry of the organs of the digestive system.

\section{MATERIAL AND METHODS}

The research behind this study was performed in an aviary from the Veterinary and Zootechnical School of the Federal University of Goiás (Escola de Veterinária e Zootecnia da Universidade Federal de Goiás), and was approved by the Ethics Committee on the Use of Animals of the Federal University of Goiás under opinion $\mathrm{N}^{\mathrm{o}}$. 039/16.

The research was conducted using 180 broiler chicks, male, from the commercial lineage line Cobb 500, distributed in a completely randomized design, with two treatments and six repetitions of 15 birds each. The treatments used were: pre-initial pelletized feed $\left(75^{\circ} \mathrm{C}\right)$ and pre-initial extruded feed $\left(150^{\circ} \mathrm{C}\right)$. The experimental feeds, pre-initial (1-7 days) pelletized and extruded, were formulated based on corn and soybean meal, which followed the recommendations of nutritional demands and feed composition of Rostagno et al. (2011) (Table 1).

The feed pelletizing process was performed as a dry pellet process, without the addition of water, using a Krabbe pelletizer, model GKPPS006100, at a temperature of $75^{\circ} \mathrm{C}$, using a matrix with holes of $2.5 \mathrm{~mm}$. For the extrusion process, the feed was submitted to a temperature of $150^{\circ} \mathrm{C}$ and $20 \%$ humidity and a matrix with $3.0 \mathrm{~mm}$ holes, using the extruder model EX30, with a capacity to process $40 \mathrm{~kg} / \mathrm{h}$. After undergoing the pelletizing or extrusion process, the feeds were dried in a forced circulation dryer at $55^{\circ} \mathrm{C}$, for 12 hours.

The length and diameter of the experimental feed pellets were measured with the aid of a digital caliper, using a sample with 20 pellets per feed. The feed pellets possessed the respective length and diameter: pelleted feed $(5.63 \mathrm{~mm}$; $2.07 \mathrm{~mm})$ and extruded feed $(4.93 \mathrm{~mm}$; $2.88 \mathrm{~mm}$ ). The experimental feeds were provided only during the pre-initial phase, from 1 to 7 days of age. During the period of 8 to 21 days of age, all the birds received an initial feed, mashed, corn based and soybean meal (Table 1). 
Table 1. Composition of broiler feeds in the pre-initial and initial phases

\begin{tabular}{lcc}
\hline INGREDIENT & Pre-initial & Initial \\
\hline Corn, grain & 51.47 & 56.40 \\
Soy, meal & 40.30 & 36.77 \\
Calcitic limestone & 0.87 & 0.89 \\
Dicalcium phosphate & 1.94 & 1.79 \\
L-lysine & 0.21 & 0.17 \\
DL-Methionine & 0.34 & 0.17 \\
L-Threonine & 0.09 & 0.01 \\
Soy oil & 3.20 & 2.84 \\
Na/bicarbonate & 0.19 & 0.16 \\
Salt (Sodium Chloride) & 0.38 & 0.38 \\
Premix Mineral and vitamin & 0.40 & 0.40 \\
Inert & 0.60 & 0.00 \\
\hline Total & 100.00 & 100.00 \\
\hline CALCULATED COMPOSITION & & 3.000 \\
\hline ME (kcal/kg) & 2.957 & 21.33 \\
Crude protein (\%) & 22.73 & 0.89 \\
Calcium (\%) & 0.92 & 0.44 \\
Available phosphorus (\%) & 0.47 & 1.14 \\
Digestible lysine (\%) & 1.34 & 0.46 \\
Digestible methionine (\%) & 0.63 & 0.74 \\
Digestible Met+Cys (\%) & 0.93 & 0.74 \\
Digestible threonine (\%) & 0.87 & 0.24 \\
Digestible tryptophan (\%) & 0.26 & 1.35 \\
Digestible arginine (\%) & 1.45 & 2.92 \\
Crude fiber & 3.02 & 0.83 \\
Potassium (\%) & 0.88 & 0.21 \\
Sodium (\%) & 0.22 & 0.28 \\
Chlorine (\%) & 0.28 & 2.89 \\
Linoleic acid (\%) & 3.03 & \\
\hline & & \\
\hline
\end{tabular}

${ }^{1}$ Mineral and vitamin supplement - PX initial broiler initial (FVI) VM24D- guaranteed levels per kilogram of product: Vitamin A 2,000,000 UI, Vitamin D3 800,000 UI, Vitamin E 5.000 U.I, Vitamin K3 450 mg, Vitamin B1 $500 \mathrm{mg}$, Vitamin B2 $1.500 \mathrm{mg}$, pantothenic acid (mg) $3.500 \mathrm{mg}$, Vitamin B6 (min) $700 \mathrm{mg}$, Vitamin B12(min) 2,500mg, Niacin (min) 9,000 mg, Folic acid (min) 250mg, biotin (min) $15 \mathrm{mg}$, choline (min) $80 \mathrm{~g}$, iron (min) 10 g, Copper (min) 2,500 mg, Manganese (min) $20 \mathrm{~g}$, Zinc (min) $18 \mathrm{~g}$, Iodine (min) $250 \mathrm{mg}$, Selenium (min) $75 \mathrm{mg}$, virginiamycin $4,125 \mathrm{mg}$, nicarbazin $10 \mathrm{~g}$, $\mathrm{mg}$, ammonium duramycin $937.5 \mathrm{mg}$.

The chicks were housed in metal batteries, divided into cages with dimensions of $0.30 \times 0.74 \times 0.79 \mathrm{~m}$, equipped with linear type feeders and drinkers. The chicks received water and feed at will. The control of temperature 
in the experimental shed was performed through gas heaters and curtain management. Temperature and humidity were measured using two thermohygrometers placed at the extremities of the shed, where temperature and relative humidity were of $32 \%$ and $56^{\circ} \mathrm{C}$ in the first week, $29 \%$ and $54^{\circ} \mathrm{C}$ in the second week and $27.5 \%$ and $61^{\circ} \mathrm{C}$ in the third week of life.

The variables studied were: performance, digestive organ morphology and metabolizable energy of feed nutrients. Performance was evaluated over the period of 1 to 7,1 to 14 and 1 to 21 days of age, where evaluations were made of live weight, weight gain, feed consumption and food conversion. The live weight was obtained by dividing the total weight of the birds in the cage, by the quantity of birds in the batch. Weight gain was obtained through the difference between the final weight and the initial weight of the birds and dividing this by the average number of birds in the batch. Feed consumption was determined by the difference between the quantity of feed offered at the beginning and the leftovers at the end of each period. Food conversion was obtained through the relationship between food consumption and weight gain of each batch. Bird mortality was reported daily for corrections to feed consumption and food conversion.

The morphometric measures of the digestive system organs was performed at 7 and 21 days of life. Two chicks per batch were sacrificed by cervical dislocation for performing morphometry of the digestive organs (Proventriculus, gizzard, pancreas and liver with the gallbladder, small intestine and large intestine). The organs were weighed on an analytical balance, precision $0.0001 \mathrm{~g}$. The values obtained were expressed in relative weight, using the formula: relative weight of the organ $(\%)=$ (weight of the organ / live weight without the yolk sac) x 100 .

The metabolic assay was performed during the period of 4 to 7 days of age, by the total excreta collection method, according to Sakomura \& Rostagno (2007). The excreta were collected twice a day ( $08 \mathrm{hrs}$ and $17 \mathrm{hrs}$ ), placed in plastic sacks and stored in a freezer. During the collection period, the quantity of consumed feed and the total quantity of excreta produced were measured.

For the bromatological analyzes, the excreta were thawed at room temperature, homogenized and dried in a forced air convection oven, at a temperature of $65^{\circ} \mathrm{C}$, for 72 hours. Quantities for dry matter and nitrogen were established from excreta and feed, in accordance with the methodology described by Silva \& Queiroz (2002) and gross energy, were established by means of bomb-type calorimeter Ika, model C200. F. The nutrient metabolization coefficients were calculated by means of equations proposed by Sakomura and Rostagno (2007). The values of metabolizable energy were calculated using the equations of Matterson et al. (1965).

The data were submitted to analysis of variance (ANOVA) and the means were compared by the $\mathrm{F}$ test at $5 \%$ probability. The data were analyzed with the aid of the statistical software R.

\section{RESULTS AND DISCUSSION}

Noted during the period from 1 to 7 days of age was the difference $(\mathrm{P}<0.05)$ between the pelletized feed and extruded 
feed for feed consumption (Table 2). Chicks that consumed extruded feed presented lower feed consumption in the pre-initial phase. During the period of 1 to 14 and from 1 to 21 days of age, the thermal processing of pre-initial feed had an influence of $(\mathrm{P}<0.05)$ on live weight, weight gain, feed consumption and food conversion, where chicks that consumed extruded pre-initial feed presented the worst results, when compared to chicks that consumed pelletized feed.

Table 2- Performance of broiler chicks fed on pre-initial pelleted or extruded feed from 1 to 21 days of age.

\begin{tabular}{lcccc}
\hline Processing & $\begin{array}{c}\text { Final weight } \\
(\mathrm{g})\end{array}$ & $\begin{array}{c}\text { Weight gain } \\
(\mathrm{g})\end{array}$ & $\begin{array}{c}\text { Feed consumption } \\
\text { g/bird/period }\end{array}$ & $\begin{array}{c}\text { Food conversion } \\
(\mathrm{g}: \mathrm{g})\end{array}$ \\
\hline Pelletized & 177.84 & 137.25 & $144.26 \mathrm{a}$ & 1.03 \\
Extruded & 171.16 & 130.08 & $136.56 \mathrm{~b}$ & 1.05 \\
\hline Value of P & 0.098 & 0.078 & 0.040 & 0.356 \\
CV (\%) & 3.63 & 4.77 & 4.09 & 2.29 \\
\hline \multicolumn{5}{c}{1 to 14 days } \\
\hline Pelletized & $496.06 \mathrm{a}$ & $455.68 \mathrm{a}$ & $550.38 \mathrm{a}$ & $1.19 \mathrm{a}$ \\
Extruded & $452.45 \mathrm{~b}$ & $411.38 \mathrm{~b}$ & $514.34 \mathrm{~b}$ & $1.26 \mathrm{~b}$ \\
\hline Value of P & 0.003 & 0.002 & 0.035 & 1.66 \\
CV (\%) & 4.50 & 4.86 & 5.09 & $1.29 \mathrm{a}$ \\
\hline \multicolumn{5}{c}{1 to 21 days } \\
Pelletized & $971.80 \mathrm{a}$ & $931.41 \mathrm{a}$ & $1208.17 \mathrm{a}$ & $1.35 \mathrm{~b}$ \\
Extruded & $897.80 \mathrm{~b}$ & $843.16 \mathrm{~b}$ & $1146.10 \mathrm{~b}$ & 0.004 \\
\hline Value of P & 0.001 & $<0.001$ & 0.003 & 2.14 \\
CV (\%) & 3.15 & 2.83 & 1.68 & \\
\hline
\end{tabular}

$\mathrm{CV}=$ Coefficient of variation; of probability. Means with different letters in the same column differ between themselves in the F-test at $5 \%$.

Research on thermal processing has demonstrated different effects on broiler performance (García et al., 2008; Abdollahi et al., 2013; Teixeira netto et al., 2019; Avazkhanloo et al., 2020). These differences can occur due to the source of starch in the diet (Abdollahi et al., 2013), as well as due to factors related to thermal processing, such as time (Massuquetto et al., 2018), umidade (Al marzooqi \& Wiseman, 2009) and temperature (Teixeira netto et al., 2019). In fact, the interaction of the ingredients that constitute the diet and variables from the thermal processing determine the chemical reactions between nutrients and the end chemical-physical structure of the diet. In the current study, the extrusion temperature $\left(150^{\circ} \mathrm{C}\right)$ may produce negative effects on animal performance. Thermal treatment of feed at high temperature should be monitored in terms of the process, due to loss of thermolabile nutrients, such as vitamins (Skrivan et al., 2012), reduction in availability of amino acids (Boroojeni et al., 2014), mainly lysine, due to the Maillard reaction, in addition to resistant 
starch (Abdollahi et al., 2011). The latter is denominated as starch retrogradation, i.e., the starch that was gelatinized undergoes restructuring in its chain, forming bonds that are of difficult enzymatic digestion (Wang et al., 2015). These negative effects from high extrusion temperatures lead to low nutrient digestibility (Abdollahi et al., 2013), which may be the cause of the worse performance encountered in those chicks that consumed extruded feed.

There were noted differences observed between the thermal processing for relative weight of organs at 7 days (Table 3). The chicks fed extruded feed exhibited lower development of the gizzard, proventriculus, duodenum, jejunum and ileum $(\mathrm{P}<0.05)$, when compared to pelletized feed.

Table 3- Relative weight of digestive organs in broiler chicks with pre-initial pelletized and extruded feed at 7 to 21 days of age.

\begin{tabular}{lcccccccc}
\hline \multicolumn{7}{c}{ Weight of organs (\%) } \\
\hline Processing & Gizz & Pan & Liv & Prov & Duo & Jej & Ileu & Li \\
\hline Pelletized & $6.74 \mathrm{a}$ & 0.42 & 3.91 & $1.27 \mathrm{a}$ & $2.40 \mathrm{a}$ & $4.11 \mathrm{a}$ & $3.25 \mathrm{a}$ & 1.22 \\
Extruded & $3.00 \mathrm{~b}$ & 0.40 & 4.25 & $0.98 \mathrm{~b}$ & $2.01 \mathrm{~b}$ & $3.07 \mathrm{~b}$ & $1.93 \mathrm{~b}$ & 1.04 \\
\hline Value of P & 0.0001 & 0.350 & 0.780 & 0.006 & 0.002 & 0.007 & 0.001 & 0.132 \\
CV(\%) & 9.07 & 10.45 & 6.96 & 10.90 & 7.38 & 11.63 & 15.77 & 12.70 \\
\hline \multicolumn{7}{c}{1 to } & \multicolumn{7}{c}{1 to 21 days } & & & & \\
\hline Pelletized & $3.95 \mathrm{a}$ & 0.31 & 2.46 & 0.72 & 1.08 & 2.06 & 2.36 & 1.11 \\
Extruded & $3.37 \mathrm{~b}$ & 0.34 & 2.25 & 0.67 & 1.12 & 2.32 & 2.59 & 1.20 \\
\hline Value of P & 0.030 & 0.139 & 0.137 & 0.417 & 0.598 & 0.981 & 0.241 & 0.230 \\
CV (\%) & 9.85 & 9.84 & 9.52 & 12.46 & 10.14 & 12.10 & 10.54 & 8.59 \\
\hline
\end{tabular}

Gizz- gizzard, Pan- pancreas, Liv-Liver, Prov- proventriculus, Duo-duodenum, Jej-jejunum, Ileu-ileum, LiLarge intestine; $\mathrm{CV}=$ Coefficient of variation; of probability. Means with different letters in the same column differ between themselves in the F-test at $5 \%$.

The processing temperature can produce positive effects, such as the increase in organ weight (Boroojeni et al., 2014) or negatives, such as the reduction in digestibility of nutrients that causes a reduction in organ weight (Abdollahi et al., 2011). This negative effect may have occurred in this study, through the extrusion process at $150^{\circ} \mathrm{C}$. In addition, according to Maiorka (2004), the resistant starch, as in the case of fiber, can increase the quantity of substrate for the development of pathogenic microorganisms and the production of toxins, which go on to cause damage to the epithelium.

At 21 days of age, it was found that prestarter feed only influenced the relative weight of the gizzard $(\mathrm{P}<0.05)$, which remained lower in chicks that consumed extruded feed. Through an evaluation of the metabolizable energy of the nutrients (Table 4), a difference was noted $(\mathrm{P}<0.05)$ between the pelletized and extruded feed. 
Table 4. Nitrogen Balance values (NB, g), coefficients of metabolizable dry matter (CM $\%$ ), of the total nitrogen (CMN, \%), apparent metabolizable energy (AME, $\mathrm{kcal} / \mathrm{kg}$ ) and corrected by the nitrogen balance (AMEn, $\mathrm{kcal} / \mathrm{kg}$ ) expressed in dry matter (DM) and in natural organic matter (NOM) of pre-initial pelletized or extruded feed for chicks during the period of 4 to 7 days of age.

\begin{tabular}{lccccccc}
\hline \multicolumn{1}{c}{ Processing } & NB & CM & CMN & $\begin{array}{c}\text { AME } \\
\text { (DM) }\end{array}$ & $\begin{array}{c}\text { AMEn } \\
\text { (DM) }\end{array}$ & $\begin{array}{c}\text { AME } \\
\text { (NOM) }\end{array}$ & $\begin{array}{c}\text { AMEn } \\
\text { (NOM) }\end{array}$ \\
\hline Pelletized & 75.02 & $82.20 \mathrm{a}$ & $82.13 \mathrm{a}$ & $3,670.11 \mathrm{a}$ & $3,400.92 \mathrm{a}$ & $3,415.29 \mathrm{a}$ & $3,164.78 \mathrm{a}$ \\
Extruded & 70.06 & $79.00 \mathrm{~b}$ & $77.39 \mathrm{~b}$ & $3,120.15 \mathrm{~b}$ & $2,852.46 \mathrm{~b}$ & $2,894.70 \mathrm{~b}$ & $2,646.35 \mathrm{~b}$ \\
\hline Value of P & 0.205 & 0.025 & 0.005 & $<0.001$ & $<0.001$ & $<0.001$ & $<0.001$ \\
\hline CV $(\%)$ & 9.13 & 2.78 & 3.15 & 3.30 & 3.35 & 3.30 & 3.34 \\
\hline
\end{tabular}

$\mathrm{CV}=$ Coefficient of variation; of probability. Means with different letters in the same column differ between themselves in the F-test at 5\%.

The chicks fed with pre-initial extruded feed presented lower nitrogen balance values, metabolizable energy coefficients for dry matter, for nitrogen, for apparent metabolizable energy and corrected in dry matter and in natural organic matter, during the period of 4 to 7 days of age.

The lower metabolizable protein in the extruded feed, can be related to the Maillard reaction (Shibao \& Bastos, 2011). High temperatures during the processing of feed, can cause the Maillard reaction, which was demonstrated by the lower rate of lysine (Hendriks et al., 1994) and lower digestibility of amino acids (Carvalho et al., 2009).

The lower metabolizable energy noted in the extruded feed, can be related to the undesirable modifications in the feed nutrients, such as the formation of starch retrogradation, impairing glucose availability (Abdollahi et al., 2011; Liu et al., 2013). Starch retrogradation or type 3 resistant starch is not digested by pancreatic amylase, thus, it does not release glucose for absorption (Wang et al., 2015) and impairs energy production (Lima et al., 2016).
As such, the conclusion is reached that feed extruded at $150^{\circ} \mathrm{C}$ based on corn and soybean meal, for broiler chicks in the pre-initial phase, results in lower digestibility of nutrients and lower development of the organs of the digestive system at 7 days of age and demonstrate the worst performance at 21 days.

\section{ACKNOWLEDGEMENTS}

The authors are grateful to the National Council of Scientific and Technological Development (Conselho Nacional de Desenvolvimento Científico e Tecnológico" (CNPq)), Brazil and to the Coordination for the Improvement of Higher Education Personnel (Coordenação de Aperfeiçoamento de Pessoal de Nivel Superior" (CAPES)), Brazil, for financing the research.

\section{REFERENCES}

ABDOLLAHI, M.R.; RAVINDRAN, V.; WESTER, T.J.; RAVINDRAN, G.; THOMAS, D.V. Influence of feed form and conditioning temperature on performance: apparent metabolisable energy and ileal digestibility of starch 
and nitrogen in broiler starters fed wheat-based diet. Animal Feed Science and Technology, v.168, n.1-2, p.88-99, 2011.

ABDOLLAHI, M.R.; RAVINDRAN, V.; SVIHUS, B. Pelleting of broiler diets: an overview with emphasis on pellet quality and nutritional value. Animal Feed Science and Technology, v.179,n.1-4, p.1-23, 2013.

AL-MARZOOQI, W.; WISEMAN, J. Effect of extrusion under controlled temperature and moisture conditions on ileal apparent amino acid and starch digestibility in peas determined with young broilers. Animal Feed Science and Technology, v.153, n.1-2, p.113130, 2009.

AL-RABADI, G.J.; TORLEY, P.J.; WILLIAMS, B.A.; BRYDEN, W.L.; GIDLEY, M.J. Effect of extrusion temperature and pre-extrusion particle size on starch digestion kinetics in barley and sorghum grain extrudates. Animal Feed Science and Technology, v.168, n.3-4, p.267-279, 2011.

AVAZKHANLOO, M.; SHAHIR, M.H.; KHALAJI, S.; ANARKOOLI, I.J. Flaxseed extrusion and expansion coupled with enzyme and pelleting changed protein and lipid molecular structure of flaxseed and improved digestive enzymes activity, intestinal morphology, breast muscle fatty acids and performance of broiler chickens. Animal Feed Science and Technology, v.260, n.1, p.114341, 2020.

BOEMO, L.S.; ROSA, D.P.D.; ROSA, A.P.; ORSO, C.; SCHER, A.;
GEHRKE, S.B.; MARIANI, A.B. Processos térmicos em dietas para frangos de corte na fase pré-inicial. Revista Brasileira de Saúde e Produção Animal, v.17, n.2, p. 195201, 2016.

BOROOJENI, F.G.; MADER, A.; KNORR, F.; RUHNKE, I.; RÖHE, I.; HAFEEZ, A.; ZENTEK, J. The effects of different thermal treatments and organic acid levels on nutrient digestibility in broilers. Poultry Science, v.93, n.5, p. 1159-1171, 2014.

CARVALHO, D.C.D.O.; ALBINO, L.F.T.; VARGAS JUNIOR, J.G.D.; TOLEDO, R.S.; OLIVEIRA, J.E.D.; SOUZA, R.M.D. Coeficiente de metabolizabilidade verdadeira dos aminoácidos e valores de aminoácidos digestíveis do milho submetido a diferentes temperaturas de secagem e períodos de armazenamento. Revista Brasileira de Zootecnia, v.38, n.5, p.850-856, 2009.

DOS SANTOS, T.T.; DASSI, S.C.; FRANCO, C.R.; DA COSTA, C.R.; LEE, S.A.; DA SILVA, A.V. F. Influence of fibre and betaine on development of the gastrointestinal tract of broilers between hatch and $14 \mathrm{~d}$ of age. Animal Nutrition, v.5, n.2, p. 163173, 2019.

EBLING, P.D.; KESSLER, A.M.; VILLANUEVA, A.P.; PONTALTI, G.C.; FARINA, G.; RIBEIRO, A.M.L. Rice and soy protein isolate in prestarter diets for broilers. Poultry Science, v.94, n.11, p.2744-2752, 2015.

FREITAS, E.R.; SAKOMURA, N.K.; DAHLKE, F.; SANTOS, F.R.; 
BARBOSA, N.A.A. Desempenho, eficiência de utilização dos nutrientes e estrutura do trato digestório de pintos de corte alimentados na fase pré-inicial com rações de diferentes formas físicas. Revista Brasileira de Zootecnia, v.37, n.1, p.73-78, 2008.

GARCÍA, M.; LÁZARO, R.; LATORRE, M.A.; GRACIA, M.I.,; MATEOS, G.G. Influence of enzyme supplementation and heat processing of barley on digestive traits and productive performance of broilers. Poultry Science, v.87, n.5, p.940-948, 2008.

HENDRIKS, W.H.; MOUGHAN, P.J.; BOER, H.; VAN DER POEL, A.F.B. Effects of extrusion on the dye-binding, fluorodinitrobenzene-reactive and total lysine content of soyabean meal and peas. Animal feed science and technology, v.48, n.1-2, p.99-109, 1994.

LAMOT, D.M.; VAN DE LINDE, I.B.; MOLENAAR, R.; VAN DER POL, C.W.; WIJTTEN, P.J.A.; KEMP, B.; VAN DEN BRAND, H. Effects of moment of hatch and feed access on chicken development. Poultry Science, v.93, n.10, p.2604-2614, 2014. LEESON, S.; SUMMERS, J.D.

Commercial Poultry Nutrition.

Canada: University of Guelph, 2005, 413p.

LIMA, M.F.; COUTO, H.P.; REAL, G.S.C. P.; SOARES, R.T.R.N.; GOMES, A.V.C.; CURVELLO, F.A. Valores energéticos de rações expandidas em diferentes temperaturas para frangos de corte. Arquivo

Brasileiro de Medicina Veterinária e Zootecnia,. v.68, n.3, p.725-732, 2016.
LIU, S.; SELLE, P.H.; COWIESON, A.J. Influence of white-and redsorghum varieties and hydrothermal component of steam-pelleting on digestibility coefficients of amino acids and kinetics of amino acids, nitrogen and starch digestion in diets for broiler chickens. Animal Feed Science and Technology, v.186, n.1, p.53-63, 2013.

MAIORKA, A. Impacto da saúde intestinal na produtividade avícola. In: V Simposio Brasil Sul de Avicultura, 2004.Universidade Federal Do Paraná, Brasil. Disponível em: $<$ http://www.cnpsa.embrapa.br/sgc/sgc publicacoes/anais_V_bsa_Alex.pdf $>$ Acessado em: 12 de março de 2019.

MASSUQUETTO, A.; DURAU, J.F.; SCHRAMM, V.G.; NETTO, M.T.; KRABBE, E.L.; MAIORKA, A. Influence of feed form and conditioning time on pellet quality, performance and ileal nutrient digestibility in broilers.

Journal of Applied Poultry Research, v.27, n.1, p.51-58, 2018.

MATTERSON, L.D., POTTER, L.M., STUTZ, M.W.; SINGSEN, E.P. The metabolizable energy of feeds ingredients for chickens. Research Report, Storrs, Connecticut, The University of Connecticut, Agricultural Experiment Station, 1965. p.11.

ROSTAGNO, H.S.; ALBINO, L.F.T.; DONZELE, J.L.; GOMES, P.C.; OLIVEIRA, R.F.; LOPES, D.C.; EUCLIDES, R.F. Tabela brasileira para aves e suínos: composição de alimentos e exigência nutricional. Viçosa: UFV, 2011, 187p. 
SAKOMURA, N.K.; ROSTAGNO, H.S. Métodos de pesquisa em nutrição de monogástricos.

Jaboticabal: Funep; 2007. 283 p.

SHIBAO, J.; BASTOS, D.H.M.

Produtos da reação de Maillard em alimentos: implicações para a

saúde. Revista de. Nutrição, v.24, n.6, p.895-904, 2011.

SILVA, D.J.; QUEIROZ, A.C. Análise de alimentos (métodos químicos e biológicos). Viçosa: UFV; 2002. 165p.

SKRIVAN, M.; ENGLMAIEROVÁ, M.; BUBANCOVÁ, I.; DLOUHÁ, G. The stability of vitamin $\mathrm{C}$ and other vitamins in the diets of breeding hens.

Animal feed science and technology, v.177, n.4, p.253-258, 2012.

NETTO, M.T.; MASSUQUETTO, A.; KRABBE, E.L.; SUREK, D.;

OLIVEIRA, S.G.; MAIORKA, A.

Effect of Conditioning Temperature on Pellet Quality, Diet Digestibility, and Broiler Performance. Journal of Applied Poultry Research, v.28, n.4, p.1-11. 2019.

WANG, S.; COPELAND, L.; NIU, Q. WANG, S. Starch retrogradation: A comprehensive review. Comprehensive Reviews in Food Science and Food Safety, v.14, n.5, p.568-585, 2015. 